\title{
Paul Stewart
}

\section{When Now?}

\section{Samuel Beckett's Footfalls, theatrical chronology and memory}

10:17, Wednesday morning of the $3^{\text {rd }}$ November 1999 in Lefkosia, Cyprus. In short, now. A breeze, and one can begin to detect a slight chill beneath the otherwise blue sky. The clocks went back four days ago. The now evolves as evolves reveals itself across the screen of the computer in my office. And now the office is now, or was, for was is now. Now now.

There is a play by Samuel Beckett called Footfalls, written between $2^{\text {nd }}$ March 1975 and November of that year, first published in 1976 and first performed at the Royal Court Theatre in London on the $20^{\text {th }}$ May of that year; it has been part of the repertoire of Beckett's shorter plays ever since.

Footfalls is a play in four movements, enacted between a figure on stage, May, and a voice off-stage, that of May's mother. Throughout the first three phases, May (her age given as being somewhere in her forties), who is dressed in a long, distressed, pale grey dress, paces the dimly lit front of stage with obsessive precision, her feet shuffling upon the boards. The first movement is a dialogue between the pacing May and the voice of the mother. The mother is ailing, and yet she admonishes May for "revolving it all" in her mind. A darkness, punctuated by a chime, separates the first movement from the next in which only the voice off-stage speaks. The voice directs the audience's attention to May's repetitive pacing and provides a touch of invaluable information; that the strip upon which May walks was once carpeted, but that it was removed as May "must 
hear the feet, however faint they fall;" that May still sleeps, but standing with her head resting upon the fourth wall through which the audience watches. Darkness and a fainter chime. "Sequel" heralds the third motion in which May relates the tale of Mrs Winter and her daughter Amy. Mrs Winter is disquieted by a sense of something amiss at Evensong. Her daughter cannot help her: "I was not there." Yet Mrs Winter insists: "I heard you say Amen. [...] How could you possibly have said Amen if, as you claim, you were not there?" The tale closes with Mrs Winter admonishing her daughter: "Will you never have done [...] revolving it all?" Darkness, a still fainter chime, and the fourth movement reveals a stage with "no trace of May" (p. 403).

As with so many of Beckett's later, perhaps more elusive, works, the literature surrounding Footfalls has often been of an explanatory nature. James Knowlson and John Pilling in The Frescoes of the Skull: The Later Prose and Drama of Samuel Beckett included this "miniature and delicate drama" in a consideration of the "Ends and Odds" of drama after Endgame. Knowlson (responsible for the drama section of the volume) delicately traces the development of the play and its theatrical impact, arguing that for an audience Footfalls "could succeed in the theatre at a level which involved the senses and the emotions rather more than it did the intellect." ${ }^{2}$ However, on more composed scrutiny, the play reveals an extraordinary level of parallelism and juxtaposition of sound and silence, combined with tantalising textual suggestions which fail to coalesce into an explanation of the events witnessed. Knowlson argues that May “is Beckett's own poignant recreation of a girl who had never really been born,"3 a concept that comes from a lecture given by C.G. Jung which Beckett attended in the midthirties, ${ }^{4}$ and adds: "If Jung's girl patient has haunted Beckett for so long, it is

${ }^{1}$ Samuel Beckett. "Footfalls." The Complete Dramatic Works of Samuel Beckett. London: Faber and Faber, 1990, pp. 397-403, p. 401. All parenthesised references are to this edition.

${ }^{2}$ James Knowlson and John Pilling. Frescoes of the Skull: The Later Prose and Drama of Samuel Beckett. London: John Calder, 1979, p. 222.

${ }^{3}$ James Knowlson and John Pilling, p. 223.

${ }^{4}$ The interest in the possible influence of Jungian psychoanalysis in general and the lecture which Beckett attended in particular is worthy of explanation. The lecture in question was given in London on $2^{\text {nd }}$ October 1935, whilst Beckett was receiving treatment with the psychotherapist, Alfred Bion. Jung's mention of a patient whose troubles stemmed from never truly having been born are used to their fullest extent in Beckett's radio play All That Fall (1956). Mrs Rooney recalls attending a lecture given by "one of these new mind doctors" in the hope "he might shed a little light on my life long preoccupation with horses' buttocks." She continues her story: "I remember his telling us the story of a little girl, very strange and unhappy in her ways, and how he treated her 
because she epitomized for him a permanent sense of existence by proxy, of being absent from true being."

This purportedly Jungian aspect of the play has come in for great attention, and might even be said to now form part of the Beckett critic's stock issues. Rosemary Pountney in her Theatre of Shadows, ${ }^{6}$ also takes the Jungian moment into account, whilst perhaps best illustrating the most common critical approach to the play; the delineation of Beckett's painstaking structural conception. Not only does Footfalls rely on cyclic and linear patterning, but also on those of movement and rest, and sound and silence. Such work brings us a valuable increase in understanding of the movements and emotional motions of Footfalls, at the same time as understanding Beckett's theatre in terms one might think more appropriate to music, but which prove to provide admirable insights. Interpretation per se has been passed over as a perhaps naïve pursuit; the gap being filled with a consciousness of pain, longing and the inability to resolve mental or emotional distress which the play certainly bears witness to and creates within the audience.

The difficulty of interpreting Footfalls, of unlocking quite why it is so powerful a piece of theatre, has not prevented the critic's ability to know a considerable amount about the gestation and presentation of the work. Pountney's volume helpfully includes a detailed description and discussion of Beckett's drafts of Footfalls, which reveal the author's methodology:

His careful planning, his rigorous and repeated self-analysis while structuring a text, his steady enrichment of language, [are] evident as matters of general practice. At the same time [...], the content of the text tends to move from direct to indirect statement, leaving the greatest possible latitude to the audience's imagination.

unsuccessfully over a period of years and was finally obliged to give up the case. He could find nothing wrong with her, he said. The only thing wrong with her as far as he could see was that she was dying. [...] When he had done with the little girl he stood there motionless for some time, quite two minutes I should say, looking down at his table. Then he suddenly raised his head and exclaimed, as if he had had a revelation, The trouble with her was she had never really been born" (Complete Dramatic Works of Samuel Beckett, pp. 195-96). That the lecture stayed in Beckett's memory for some time is almost certain; what significance we thereby place upon it, is not.

${ }_{6}^{5}$ James Knowlson and John Pilling, p. 228.

${ }^{6}$ Rosemary Pountney. Theatre of Shadows: Samuel Beckett's Drama 1956-1976. Gerrards Cross: Colin Smythe, 1988.

${ }^{7}$ Rosemary Pountney, p. 288. 
Helpfully, perhaps, one has recourse when writing of Footfalls not only to the text in performance - despite the scarcity of such - but also to rehearsal reports, the printed text, and the drafts of the play in what amounts to a chronology of development.

The question of chronology, which forms the substance of this article, is raised by a brief section in the third movement of the play. May is telling her story. Or telling her story of another mother and another daughter:

([May] Resumes pacing. After one length halts facing front at L[eft]. Pause) Old Mrs Winter, whom the reader will remember, old Mrs Winter, one late autumn Sunday evening, on sitting down to supper with her daughter after worship, after a few half-hearted mouthfuls laid down her knife and fork and bowed her head. What is it, Mother, said the daughter, a most strange girl, though scarcely a girl any more...

Now: Old Mrs Winter, whom the reader will remember? The audience of a play, at a precise location on a specific date, at a specific time, hears that they, perhaps, should not be the audience but the reader. As a reader they would be able to remember this Old Mrs Winter. They could leaf back through the pages of the text, find Old Mrs Winter and so be reminded.

This option to remember textually is not open to the audience of the play, and this rather basic fact creates a number of consequences. We would like to think, and do think, that one views a play rather differently than one reads a text upon which performance is built. The book is a complete object. The end of a novel may be problematic, we may feel that more is to be explained or that the story could be usefully continued, but it undeniably physically ends. The physicality, the thereness, of the book, is one of its great strengths in that even upon picking up a volume for the first time, without even so much as reading a word, we know what will be read is literally and figuratively bound. On finishing this bound, finite, physical object, we then have the luxury of recourse to the continuing thereness of the book, to the possibility of it being re-read, made present, or re-presented, once again.

An aside. In Dissemination, Jacques Derrida writes of the objections to writing spoken by Thamus in the Phaedrus. King Thamus takes on the role of judge of this new art, and upbraids Theuth, his master of arts, for being somewhat disingenuous in his defence of writing: 
[...] since you are father of written letters, your paternal goodwill has led you to pronounce the very opposite of what is their real power. The fact is that this invention will produce forgetfulness in the souls of those who have learned it because they will not need to exercise their memories, being able to rely on what is written, using the stimulus of external marks that are alien to themselves rather than, from within, their own unaided powers to call things to mind. So it's not a remedy for memory, but for reminding, that you have discovered. ${ }^{8}$

Thamus' objection can be characterised as being that writing poses a danger to memory, precisely because it functions as an aide memoire: "it is precisely by pointing out [...] that the pharmakon of writing is good for bypomnhypo (rememoration, recollection, consignation) and not for mnmnr (living, knowing knowledge) that Thamus in the Phaedrus, condemns it as being of little worth." We do not have to remember, because the text will always remember for us. There is a sly joke here on Beckett's part. The audience is told it should be a reader, because then they would remember Old Mrs Winter, when the act of reading about Old Mrs Winter means one need not remember at all.

In contrast to the continuing inanimate thereness of the written, the theatrical experience is one in which immediacy is the chief good. Stanton B. Garner, Jr., in his study of narrative comprehension in the theatre, has stated the difference admirably:

On the more fundamental levels of perception and cognition, and in terms of narrative function, the author's presence is not felt in the theater as it is felt in so many ways in the printed text. The movement from script to performance liberates the play from its exclusively linguistic embodiment: language becomes speech, directions become mise-en-scène, implied presence becomes performance reality. Production realizes the play as something outside the printed text, and as such it stands on its own, shaped only invisibly by the text it seeks to embody. ${ }^{10}$

When writing of Beckett's later plays (particularly Not I and Footfalls), Garner emphasises the very theatricality of them, the manner in which "Beckett effects an unprecedented disclosure of the theatrical moment, allowing it a substance and a

\footnotetext{
${ }^{8}$ Jacques Derrida. Dissemination. Trans. Barbara Johnson. London: Athlone, 1993, p. 102.

Jacques Derrida, p. 91.

${ }^{10}$ Stanton B. Garner Jr. The Absent Voice: Narrative Comprehension in the Theater. Urbana and Chicago: University of Illinois Press, 1989, p. xiv.
} 
place within his action unrivaled in the dramatic canon [through a] theatrical heightening of the present's inertness."11 Of the final movement of Footfalls, in which the stage is empty but filled with the resonance of presence, Garner writes:

The revolvings of figure and voice yield to the performance field that has supported them, a space that constitutes their theatrical ground of being and that asserts (in this final image) the essence of mise-en-scène. By boldly closing with an image of the stage, Beckett brings to the forefront that immediacy that is the ground of all drama... ${ }^{12}$

Garner's terms and his reading of Footfalls are quite revealing as to why Beckett's reference to a privileged reader within the dramatic context of the play is upsetting: the author's presence is not felt in the theatre. Normally this is a theatrical boon, allowing for the increased immediacy of a drama unfolding before us on a fully realised, no matter how scantily dressed, stage. In Footfalls, however, this is felt not as the removal of a textual restriction but as nothing less than a lack. The audience does not have access to that authorial, or textual, presence which appears to be the condition for fully understanding what is occurring upon, or perhaps now behind or beyond, the stage. As such, the theatrical space is revealed not as autonomous and complete within itself, but as dependent and hence lacking.

Why should the reference to some prior text, and an enjoinder for an audience to perform the functions of a reader be of itself upsetting? ${ }^{13}$ Clearly, one could argue that there is nothing remarkable in Beckett reminding the audience in the theatre that there is a text beyond the play that is seen before them now. We all know that the most common condition for theatrical representation is first the presence of a text to be performed. We are relieved by this, even: if we did not fully understand King Lear, we can always pick up a copy in the theatre book shop and read what we first saw on the stage. We are not so naïve as to think that the play simply appears before us. However, and again as Garner's insights make clear, there is a condition placed on the text if theatrical representation is to occur:

\footnotetext{
${ }^{11}$ Stanton B. Garner Jr, p. 150.

${ }^{12}$ Stanton B. Garner Jr, p. 167.

${ }^{13}$ For example, Garner does mention the Old Mrs Winter line in which the reader is mentioned, but does so only as an example of "the formulaic constructions of literary narrative" (p. 165) with which May tells her story. He does not address the issue of the literary within the theatrical context, nor of the reader; a consideration which might lead to a complication of Garner's emphasis upon Beckett's prime concern with theatrical immediacy.
} 
it must disappear. If the theatre's chief strength lies in its immediacy, in the power of embodiment or of realisation of action and language in real time, then any previous incarnation must needs be suppressed. The overt presence within a theatrical context of the play's previous existence as a written text threatens the theatre's claim to autonomy and damages the sense of immediacy which the audience expects. To use an amateurish analogy, there is nothing more upsetting or embarrassing for an audience sat to an amateur production than the hissed lines of the prompt from the wings when the actor on the stage dries. All our belief is shattered, and the realisation of theatrical time and space is destroyed by the realisation that the stage is surrounded by dressing rooms, wings, technicians, and a script. Immediacy, therefore, is dependent upon the absence of the written. The play text must absent itself awhile if the performance is to enjoy any life at all. The sacrifice of the text, perhaps.

A further aside. Beckett translated Footfalls into German and directed its new incarnation at the Schiller-Theater Werkstatt, Berlin, in 1976. Walter D. Asmus, the director nominally in control of That Time and Footfalls, during that time made detailed notes of events in rehearsal. ${ }^{14}$ (The rehearsals were always between 10.00 a.m. and 2.00 p.m.) Asmus' record provides a valuable insight into the interaction between the author and those charged with performance. As might be expected, the actress playing May, Hildegard Schmahl, who was becoming increasingly involved in "politically motivated theatre," had some difficulties in getting her performance correct. Understandably she wanted some form of motivation for her character's words and actions, yet Beckett was famously chary of giving such tips. The Old Mrs Winter difficulty arises and the difficulty appears to have been about the reader therein. In order to help, Beckett first tries to place the written in terms of May's character. Beckett was reported (in writing) as saying on Thursday, $2^{\text {nd }}$ September 1976: "One can suppose that she has written down everything which she has invented up to this, that she will one day find a reader for her story - hence the address to the reader." Still Beckett insists on the importance of the written. On Monday, $6^{\text {th }}$ September, Ms. Schmahl appears to be still unhappy, and Beckett tries a different tack: "It shouldn't give the impression of something already written down. May is inventing her story while she is speaking." This little insight into the instructions given to one of the many Mays is a curious slide in which Beckett gradually shifts

is Walter D. Asmus. "Rehearsal Notes of the German Premiere of Beckett's That Time and Footfalls." The Journal of Beckett Studies, Vol. 2 (Summer, 1977), pp. 82-96. 
his explanations with the possible aim of making them seem less upsetting to the theatrical context. Beckett's use of the reader is, I am arguing, beyond performance, but such cannot be the motivation for the woman who says it upon the stage, for Beckett's structural use threatens the immediacy of the actress' stage utterance. The two motivations - of the playwright and the actress - must be different. Put another way, Beckett knows he must absent himself if the actress is to perform theatrically. So the sacrifice of the text may also mean the sacrifice of its author. In the production in Berlin, this meant a tactical withdrawal on Beckett's part, as on Thursday, $16^{\text {th }}$ September he told the increasingly frustrated Schmahl that "I will leave you alone for a few days." He duly did.

We return to now, and now is, perhaps more than any other aspect, precisely what is upset by Beckett's mention of the privileged reader. The audience is made aware of the absent text, and thereby also aware of a certain lack in what they are witnessing on stage. They are not able to perform the action which the play recommends. They cannot remember as a reader remembers. All they have is the action upon the stage which unfolds in a series of nows; a series of actors' nows and a series of the audience's nows. Now May moves from right to left, now she stops, now she says "Old Mrs Winter, as the reader will remember..." The audience has little choice, and expects no less than to be taken along a chronological journey, a narrative in which the time of the play, no matter if it employs devices such as the flash-back, or characters referring to a past, moves forward. The time of the stage is the time of the actors and the audience. We are all caught in this inexorable march into the future which is constantly subsumed by the present. One could say that the presence of the theatre is dependent upon the present; therein lies its unique claim to immediacy. More than any other medium, the theatre has the power of representing things in a here and a now shared by the play, the actors and the audience.

The privileged reader of Footfalls reveals a question of what is the now of theatre. The audience within the theatrical now is informed that there is a then antecedent to this now. They are told now that they should perform an action which recalls the absent text, the text which occurs beyond the now of performance and the absence of which is essential for theatre's ability to perform now and now and now. The present of the play indicates a prior textual presence in which, one hopes, one might find the means to fill the lack of knowledge in this matter of Old Mrs Winter. The audience is confronted with the realisation that the realisation they see before them now is insufficient. And in that very 
moment when May says "Old Mrs Winter, as the reader will remember," in that precise, shared theatrical now it is implied that only another now, that of the written, can satisfy the apparent lack. The absent text completes a stage absence, and the now of theatrical presentation is threatened by the repeatable, representable now of the text.

In this situation which I am delineating within Footfalls, the audience is caught between two claims of chronology. On the one hand, we have the chronology of the theatre. This is happening now. The audience understands, witnesses and shares this now as it slips into further and no less immediate nows. Yet one of these nows refers to a now in which the audience does not share: the now of the written, which within the chronology of the theatre comes before the now of the stage. The discomfort of this perhaps lies in the audience's belief in their own privileged position within the theatre. They are accustomed to being first hand witnesses to current events. Yet, in Footfalls, the audience is made aware that their now of sitting in the dark watching the stage is not the ideal now of the play; there may exist the perhaps more fulsome, more understandable now of the written.

The necessary condition for theatrical immediacy is the absence of the written text, and it is this immediacy which Beckett threatens. It is perhaps worthwhile to note that the necessary condition for this article is the existence of the text in the absence of theatrical immediacy. The continuing possibility of repeatable nows which the text promises makes possible my writing about that text and your reading it now. Now and now and now has become the possibility of tomorrow and tomorrow and tomorrow. ${ }^{15}$ Could the same have been done if there was only the immediacy of the nows of theatrical performance?

Yet a writerly smugness would not be appropriate here, for Beckett is not so black and white as not to leave such matters a little greyed. Sitting in the dark of the stalls the audience may struggle to rememter any prior mention of Old Mrs Winter in the preceding twenty minutes or so of stage action, and fail to remember any such, but the reader, who, after all, is meant to be able to remember, will actually fare no better. There is no prior mention of Old Mrs Winter.

\footnotetext{
${ }^{15}$ Rosemary Pountney also detects a Footfalls / Macbeth axis at work: "Although there is no reason to suppose that Beckett had Shakespeare in mind when he wrote Footfalls, the whole play is extraordinarily realised in these lines from Macbeth: 'Tomorrow, and tomorrow, and tomorrow [...] it is a tale / Told by an idiot, full of sound and fury / Signifying nothing'" (Rosemary Pountney, pp. 67-68).
} 
The text of Footfalls does not and never has had a prior mention of Old Mrs Winter. One could, if one were so inclined, note Rosemary Pountney's comment that "the content of the text tends to move from direct to indirect statement" and look to the drafts of the play, tracing the trace of Mrs Winter back to a more fulsome source. The search would be a vain one, for throughout Beckett's drafts for this play, there is no indication of Mrs Winter, no matter how indirect, until May mentions her and commends her to the reader's memory. (Half way through Footfalls, May takes possession of her own voice, and that of her mother is once again consigned to silence. It is this speech which will mention, for the first time, Old Mrs Winter. The speech begins with a single word. "Sequel." The audience or reader may well seek well, but that does not mean they will find Mrs Winter or the ideal now of the play.)

So, Beckett reminds the audience of the existence of a text behind the representation they see before them and refers them to this absent text, whilst at the same time referring them to a text which is not only absent from the stage but also from the play text. The audience faces a double absence: of the play text, and of the text that actually remembers, the text in which Old Mrs Winter does appear. Yet Beckett's use of the privileged reader has as its target more than just the audience in the theatre. The readers will also find themselves in the situation of not being witnesses to a prior textuality. This lack will not be filled by searching out and reading the actual prior text of Footfalls; the drafts. As such, Beckett has created a regression of absence, and this regression of absence threatens the immediacy of the theatre, and hence its life, at the same time as threatening the claims to permanence of the written. The immediacy of the theatre - the memory of which is, in Derrida's terms, mnmnr, or living, internal memory - and the continuity of the written - of bypomnhypo, or alien, fixed and monumentalised memory - are not able to contain and thereby explain the beyond in which a prior Old Mrs Winter does exist and from which she can ve remembered. Beckett plays within the possibilities of the theatre and of the written and indicates a lack, or an inability on their part to approach that which lies beyond them. We are sucked into a swirl of beyonds.

There is, perhaps, a further possibility as to why May mentions her ideal reader, why she casts her narrative as written rather than as a displaced but ever recurring memory which she cannot help but revolve in her poor mind. Derrida and Thamus' objections to writing are here again pertinent. It will be remembered that Thamus claimed that writing was a danger to living memory, that those who 
practised living, internal memory, $m n m n I$, in which events are called to the mind by the mind, would find their faculty damaged by the permanency of the written. Memory through writing is dependent upon external, alien stimuli which remind. As such, the written is the vessel of memory as it replaces mnmny with bypomnhypo; living, knowing knowledge with the fixed, monumental and dead. As Derrida puts it: "If one takes the king's word for it, then, it is this life of the memory that the pharmakon of writing would come to to hypnotize: fascinating it, taking it out of itself by putting it to sleep in a monument."

For May, the written thus offers a way of overcoming the living memory which she seems incapable of overcoming. The written is a way out of the cycle of repetition, of forever revolving it all. Once written, the memory becomes alien and external, dead within a monument of inscription. May, herself ghostly but kept alive by her own memory, motions towards the avenue of escape that writing offers. If only the mnmnn from which she suffers could be substituted with the inanimate bypomnhypo, May could then forget, for then the reader would remember, prompted by the lifelessness of the written. The reader will remember (Bypomnhypo) so May need no longer remember (mnmns). Trapped in the immediate life of the theatre, and with no true remembering text, May will continue to tread the boards of the stage, her living memory re-presented by the nows and nows and nows which her feet, no matter how faint they fall, will mark.

${ }^{16}$ Jacques Derrida, p. 105. 